\title{
PATIENTS' OPINION ON HEALTH CARE QUALITY IN MUNICIPAL (COMMUNITY) HOSPITALS IN BULGARIA
}

DOI: http://dx.doi.org/10.18509/GBP.2019.33

UDC: 316.654:614.2-052(497.2)

\author{
Elisaveta Petrova- Geretto ${ }^{1}$ \\ Zlatitsa Petrova ${ }^{2}$ \\ ${ }^{1}$ Public Health Faculty, Medical University, Sofia, Bulgaria \\ ${ }^{2}$ Executive Agency Medical Audit, Sofia, Bulgaria
}

\begin{abstract}
One of the main aims of Bulgarian health care reform is to provide timely, equal and open access to healthcare resources, which would allow for optimal healthcare, improvement of health status and increased quality of life. Bulgarian health system tendencies, particularly during the last decade are as follows: population size is diminishing, working age population is diminishing, physicians' and medical specialists' numbers are diminishing, while the number of health establishments, in particular, hospitals and hospital beds is rising, patients' numbers are increasing, financial resources dedicated to health are increasing and last but not least the number of sick days per year are also increasing. The aim of the present research is to study patients' opinion on municipal (community) hospitals with regards to medical services and to indicate possible approaches for optimizing medical services.

The opinion of 195 patients in 10 municipal hospitals has been studied. The qquestionnaire consists of 20 separate questions, quantitative and qualitative indicators are related to various characteristics. Quantitative indicator is age, while qualitative indicators are: gender; education; reasons for hospitalisation; opinion on provision of information on the disease, diagnostics, treatment, prognosis and recommendations for follow up treatment; assessment of service quality in the hospital; opinion on patients' needs; assessment of hospital organisation and patient satisfactions.

Results and conclusions: 1. Quality medical care, according to respondents, is the top priority for patient's satisfaction, followed by individual treatment for every patient. Quality of hospital building and rooms has considerably less weight. 2. Provision of detailed information on the disease, diagnostics, treatment, prognosis and recommendations for follow up treatment contributes significantly to increased patients' satisfactions. 3. In general, patients approve highly of the medical services quality, irrespective of several critical downfalls on work organisation and hospital accommodation. Yet, patients would gladly recommend the particular hospital to their families and friends. 4. Patients assess highly qualification of medical staff, technical equipment, service quality while they comment negatively underpayment of medical staff in relation to their workload and efforts.
\end{abstract}

Key words: patients, municipal hospitals, quality, patient satisfaction

\section{INTRODUCTION}

One of the main aims of Bulgarian health care reform is to provide timely, equal and open access to healthcare resources, which would allow for optimal healthcare, improvement of health status and increased quality of life. Bulgarian health system tendencies, particularly during the last decade are as follows: population size is diminishing, working 
age population is diminishing, physicians' and medical specialists' numbers are diminishing, while the number of health establishments, in particular, hospitals and hospital beds is rising, patients' numbers are increasing, financial resources dedicated to health are increasing and last but not least the number of sick days per year are also increasing. [1, 2, 3, 4, 5, 6, 7, 8, 9, 10, 11, 12, 13, 14, 15]

The aim of the present research is to study patients' opinion on municipal (community) hospitals with regards to medical services and to indicate possible approaches for optimizing medical services.

The suggested research methodology uses a system of indicators of patients' feedback, which give information about satisfaction of patients as fundamental element for quality assessment and identification of quality or safety risks.

The questionnaire includes several sections:

- Questions about patient's profile and the services he/she is using

The questionnaire is anonymous and contains information about patient's age, gender, level of education and patient's experience.

- Questions consisting of indicators of patients' satisfaction

The system of indicators includes common indicators which are applicable to all services and can, as well, be used separately. The satisfaction indicators include the following:

- Accessibility and comfort- accessible environment, room comfort, food, hygiene

- Quality of medical care, including staff, equipment, organisation of work

- Communication and information, including informed consent and opportunity of immediate contact with medical specialists.

- Overall satisfaction of the service

\section{MATERIAL AND METHODOLOGY:}

Technical units of observation are 10 municipal hospitals: Multi-profile hospital for active treatment- Lom, MHAT- Vth city hospital Sofia, MHAT- Triavna, MHATKazanluk, MHAT- Purvomay, MHAT- Momcilgrad, MHAT- Pomorie, MHATDimitrovgrad, MHAT- Karnobat and MHAT- Asenovgrad. The principle of representation was respected when selecting municipal hospitals from Northern, Southern, Central and Eastern Bulgaria as well as from small, medium and large municipalities. The opinion of 195 patients has been studied. The questionnaire consists of 20 questions, connected to different sets of indicators both quantitative and qualitative. The survey was performed between February and May 2018. [13] 


\section{RESULT ANALYSIS:}

Patients' characteristics by age, education and gender.

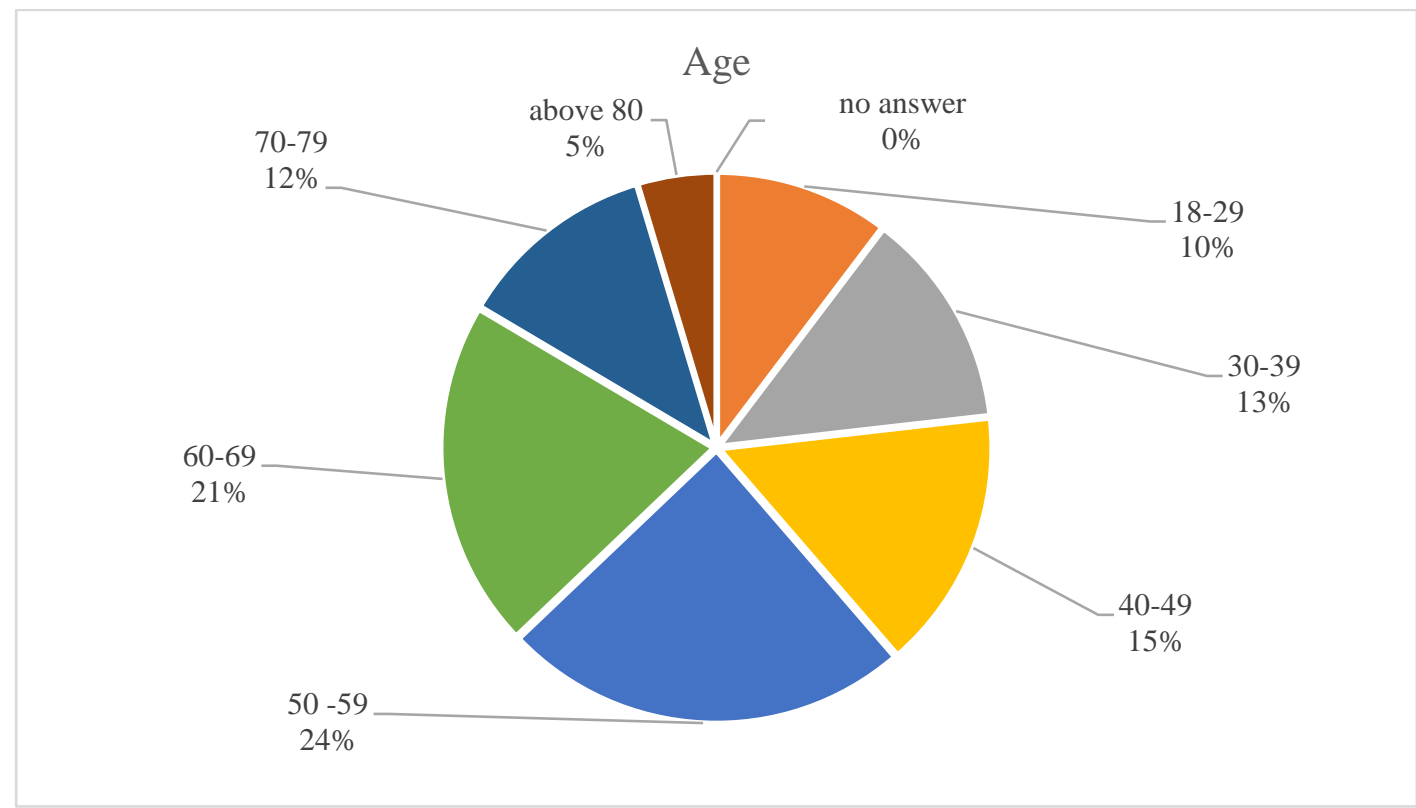

Fiture 1. Patients- age

The highest number of patients are between 50 and above 80 years of age- $62 \%$. The other $38 \%$ are between 18 and 49 years of age which directly corresponds to the demographic characteristics in these regions. Women in treatment are $67 \%$ compared to $30 \%$ of men. The reason behind can be found in the higher longevity of women and migratory processes and higher mobility of men.

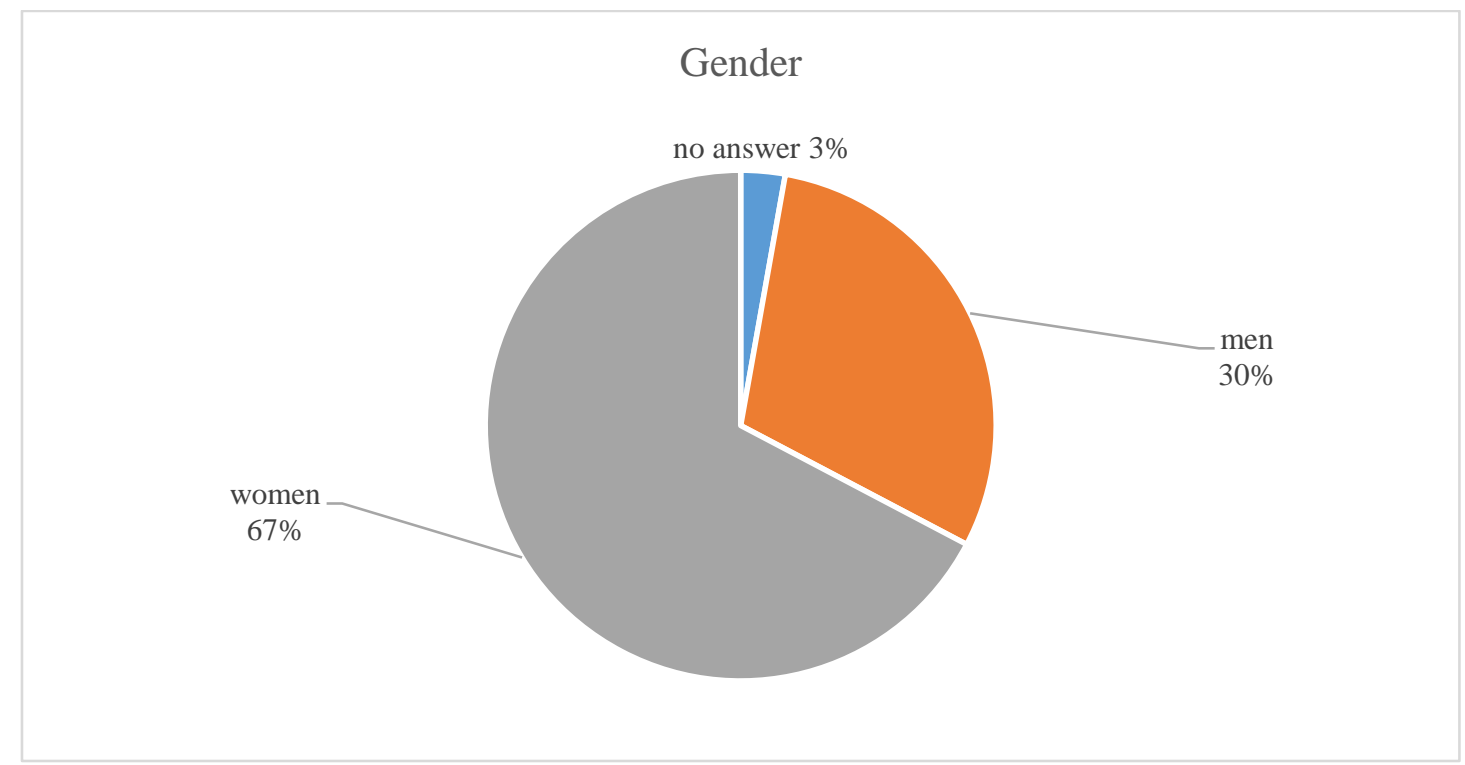

Fiture 2. Patients- gender 
Patients have predominantly secondary education (63\%), which together with patients with no education and secondary school education represent $75 \%$ of customers. These results are logical and are connected again with demographic characteristics, internal and international migration, economic status and employment.

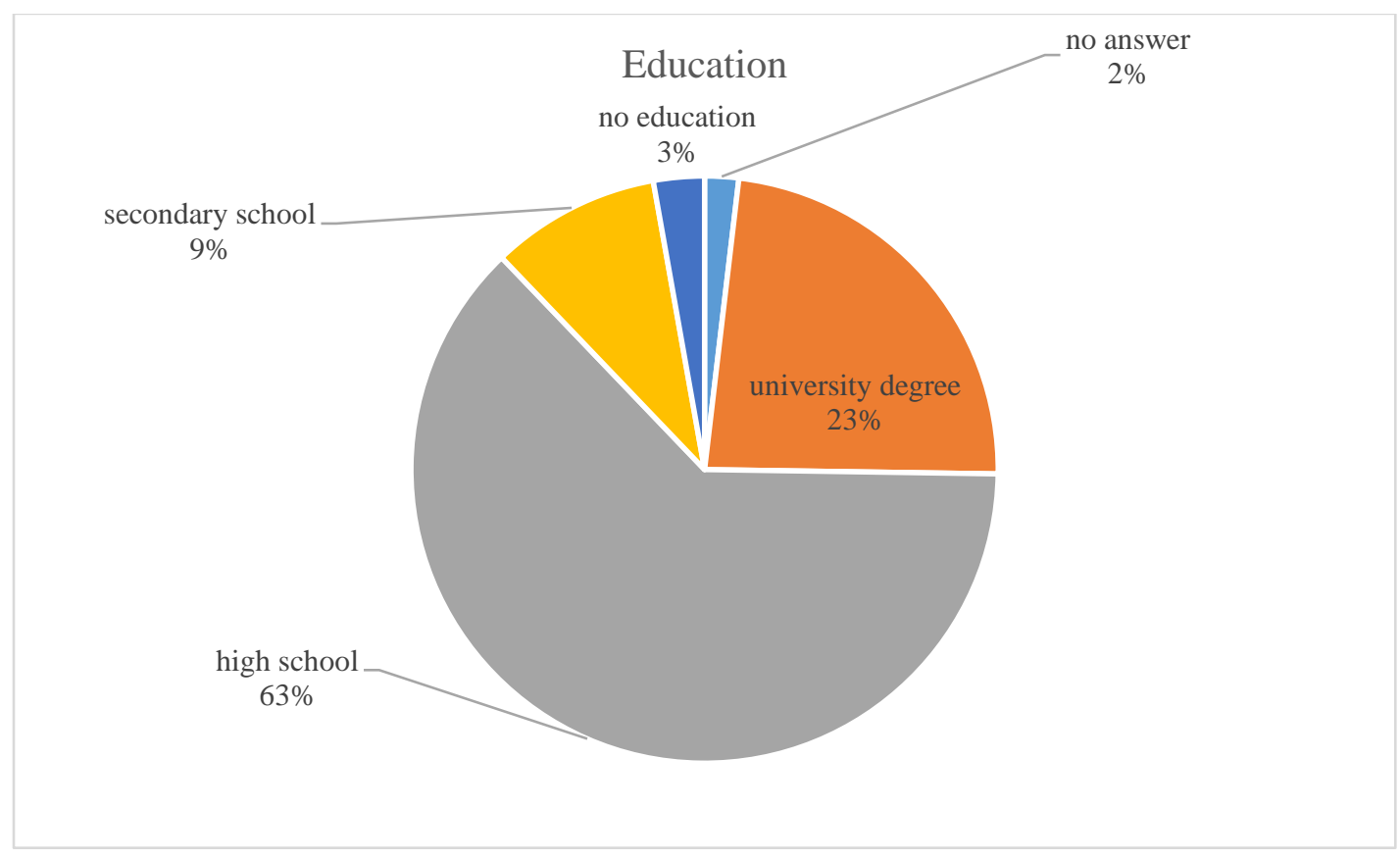

Fiture 3. Level of education

Results and discussion of qualitative questions in the patient's questionnaire.

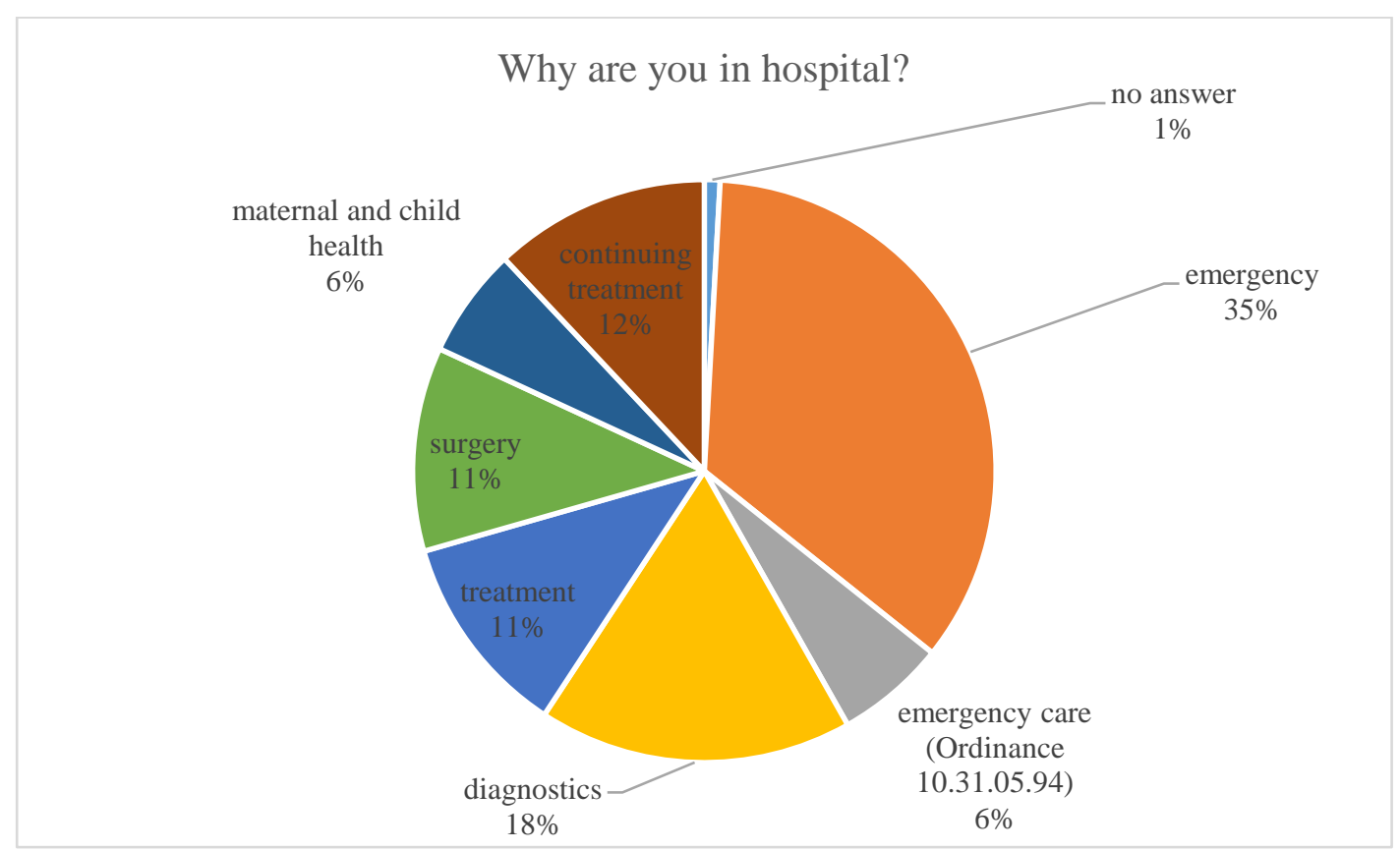

Fiture 4. Why are you in hospital? 
A very high percentage of respondents $(41 \%)$ are in hospital for emergency care. The reason behind it is that via emergency care access to hospitals is easier and also patients believe in a hospital they will get better treatment. The other $52 \%$ seek hospital care for diagnostics and treatment of therapeutic and surgical diseases, acute and chronic, while only $12 \%$ are in hospital for continuing treatment.

When answering question №5 "Why did you choose this municipal hospital”, patient rank answers as follows: trust in treating physician, vicinity to home and family, the hospital team and all of the above.

Why did you choose the hospital?

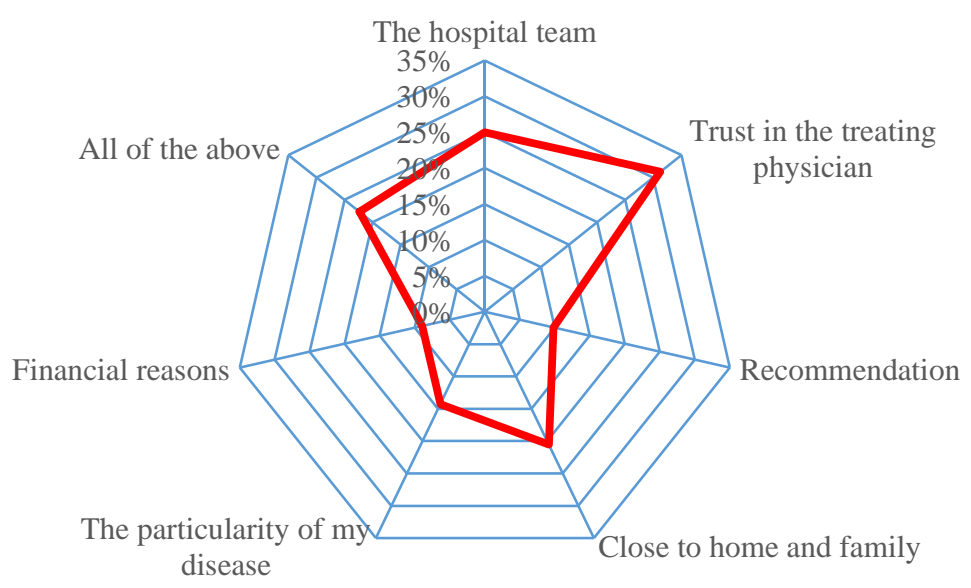

Fiture 5. Why did you choose this municipal hospital?

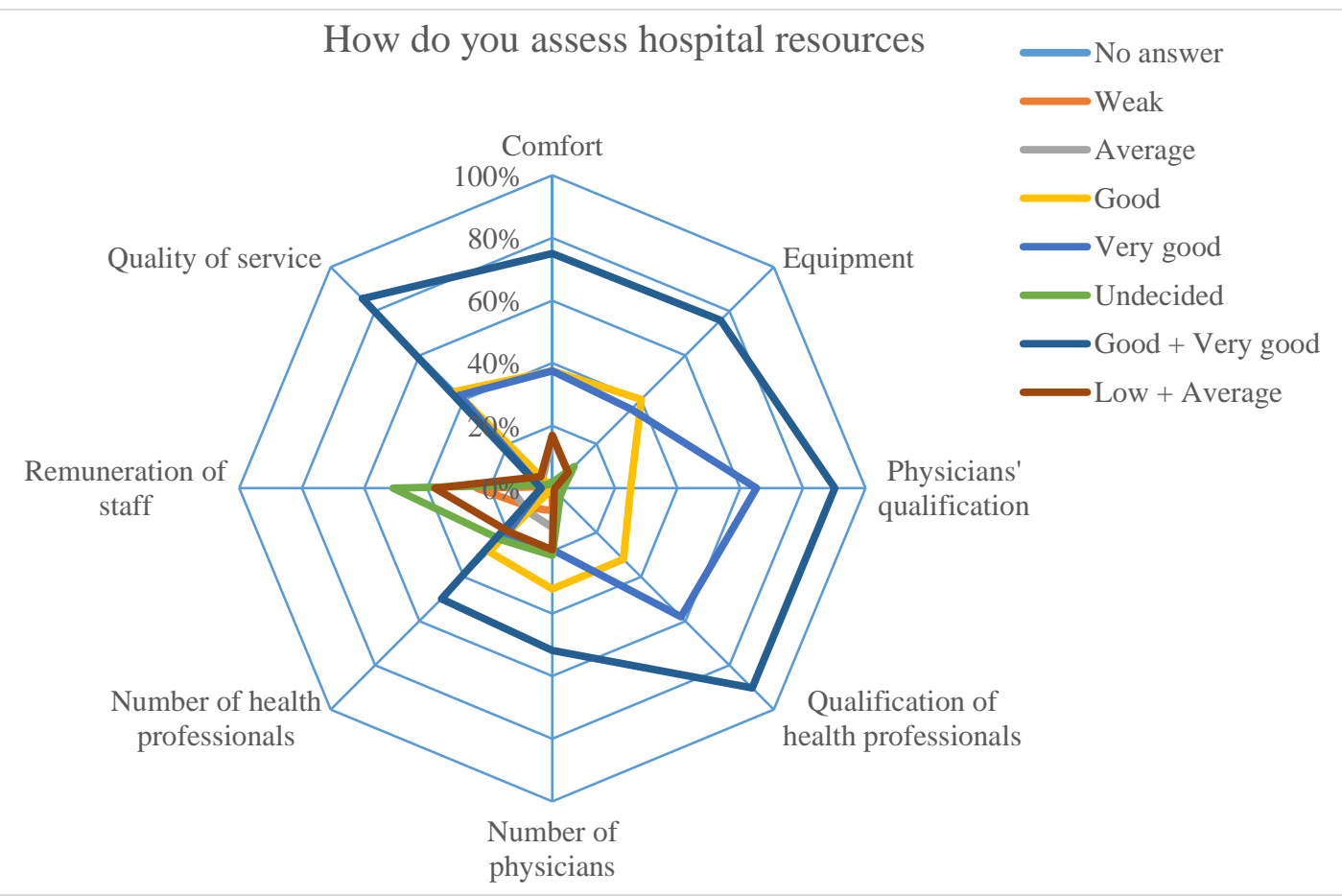

Fiture 6. Assessment of hospital resources 
Patients assessment of hospital resources rank the highest $(90 \%)$ as 'very good' and 'good' qualification of medical doctors and nurses, followed by quality of medical care (78\%), availability of equipment (40\%), patients' assessment is 'low' and 'unsatisfactory' of remuneration of medical professionals, number of medical doctors and hospital comfort.

The question "What matters the most to you as patient (patients' satisfaction measurement)", $70 \%$ respond that it is quality of service that matter the most, followed by politeness $(50 \%)$ and contemporary medical equipment (20\%). These answers confirm the hypothesis that patients care the most about quality of medical care and ethical and polite attitude from medical professionals.

What matters the most to you (patient satisfaction measurement)?

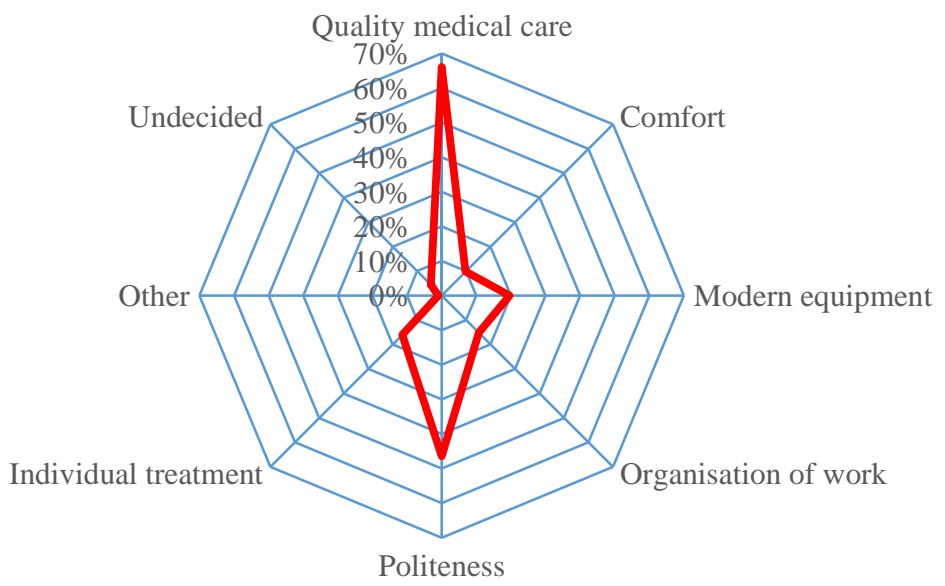

Fiture 7. What matters the most to you as patient (patients' satisfaction measurement)

A similar patient satisfaction question is "Does provision of information contribute to your higher satisfaction", linked to both informed consent and to patient's communication ability and need to receive information. More than $80 \%$ of respondents confirm that provision of information contributes to higher satisfaction from their hospital experience.

Does provision of information contribute

to your higher satisfaction?

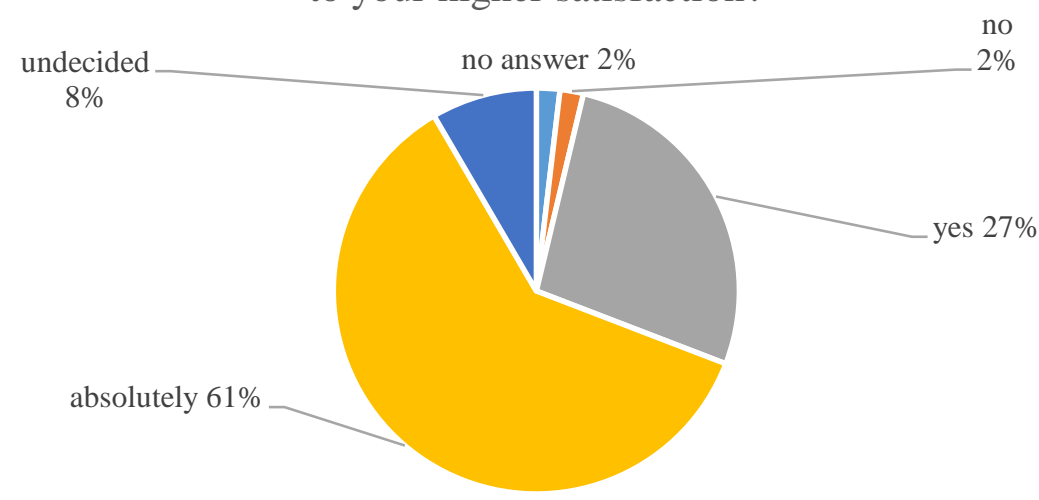

Fiture 8. Does provision of information contribute to your higher satisfaction 
The next two questions are again related to assessment of medical care, quality and professionalism at the respective municipal hospital (questions "Would you recommend your municipal hospital" and "Would you opt for treatment in a different hospital"). Over $90 \%$ of respondents give positive feedback with the positive answers: "absolutely" and "yes, to a certain degree". These answers are further confirmed by $88 \%$ of patients who claim that they prefer being treated at their municipal hospital in their home town. These results, most likely, are due to the positive assessment of diagnostic and treatment quality and the fact that most patients know their treating physicians which gives them sense of safety and security in addition to emotional connection with family and home town.

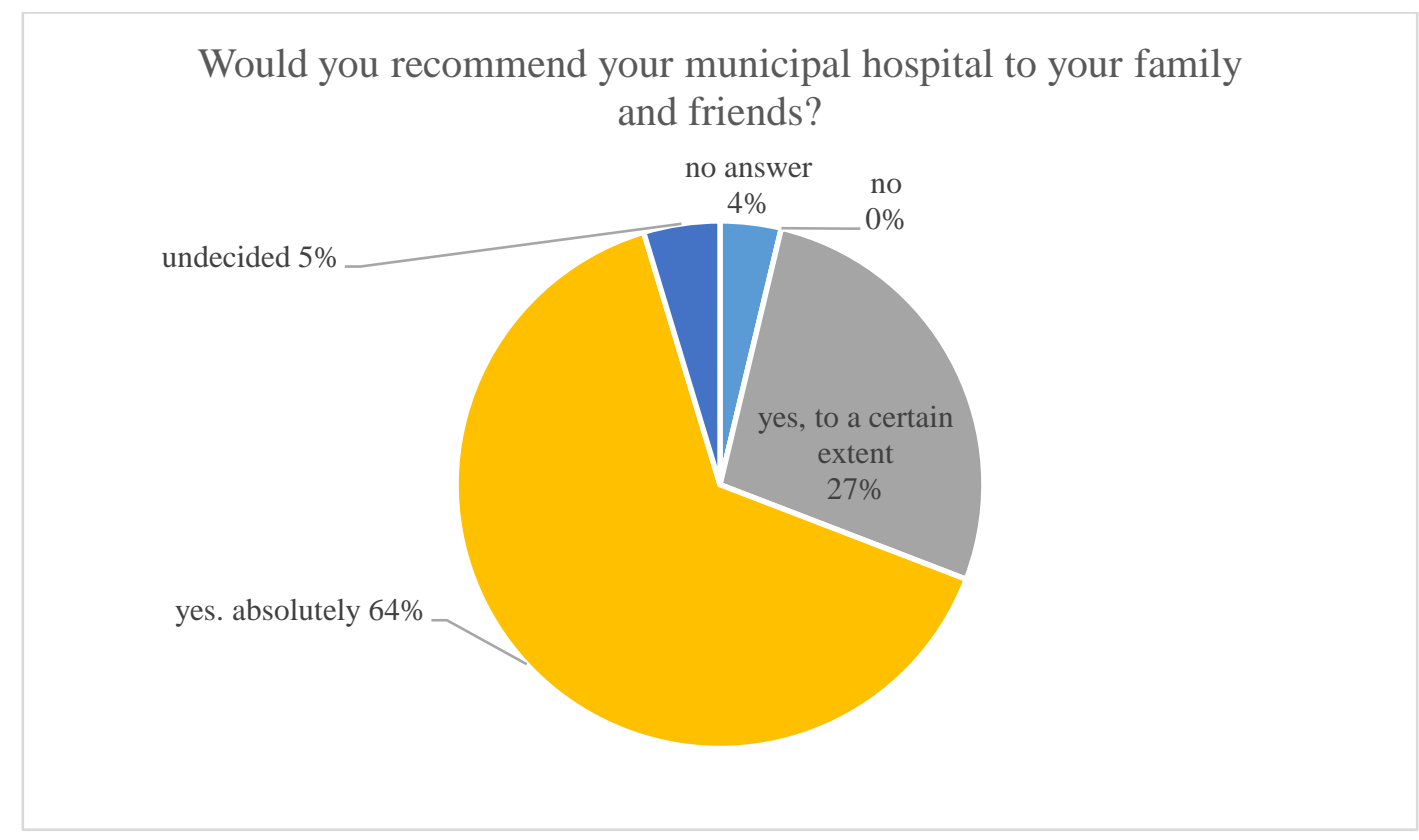

Fiture 9. Would you recommend your municipal hospital

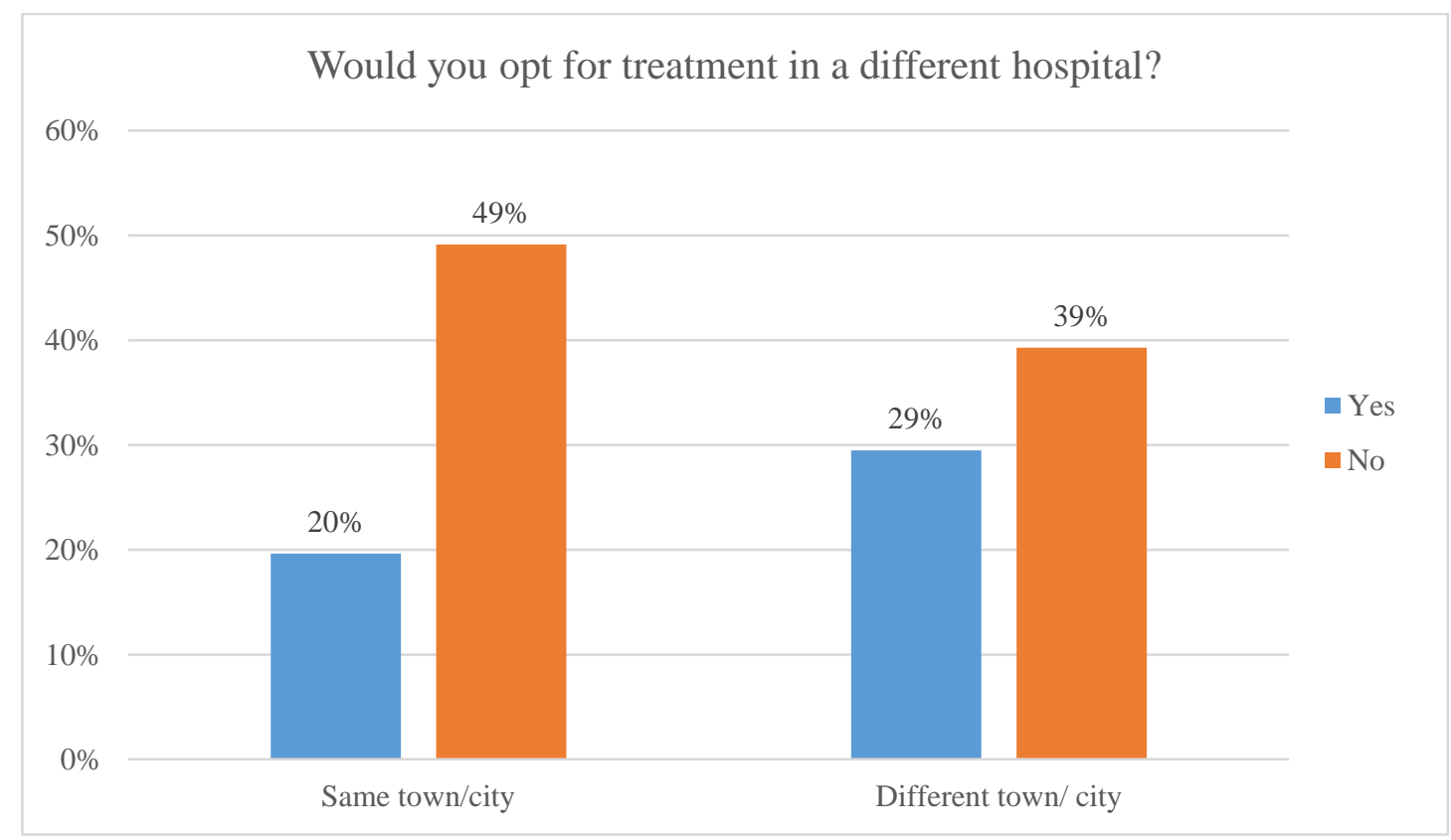

Fiture 10. Would you opt for treatment in a different hospital 
The questionnaire predominantly consists of questions related to quality of care, however we approached patients with several questions asking for recommendations/ improvements. More than half of our respondents believe that there is a lot of room for improvement in particular with regards to raising salaries and social packages of medical staff and increase the number of health professionals. These results correspond completely to the answers given by medical staff and hospital management, which means that the strongest motivating factor for providing quality care and sound management is financial security and qualification of medical staff.

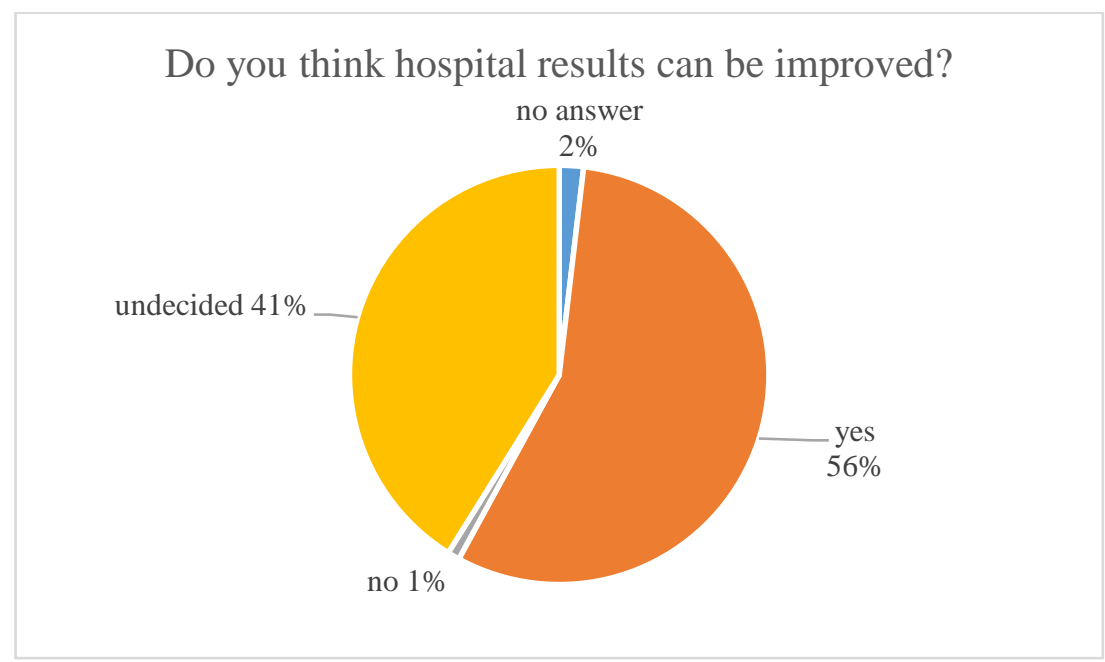

Fiture 11. Do you think hospital's results can be improved?

How do you think hospital work performance can be improved?

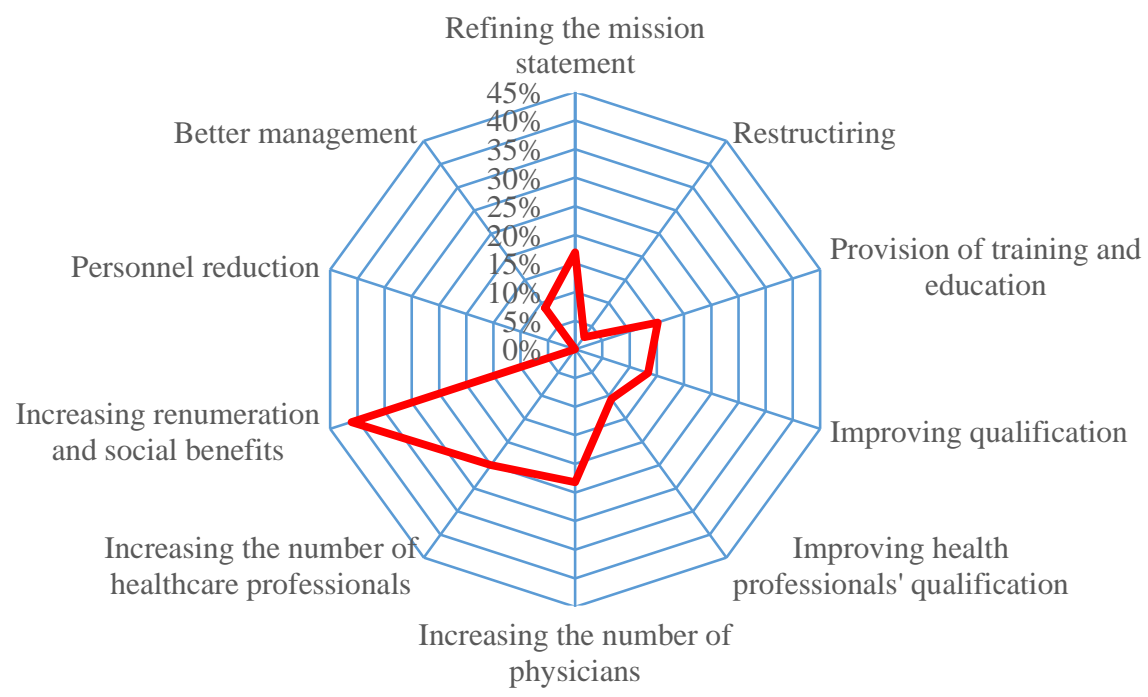

Fiture 12. How do you think hospital work performance can be improved? 


\section{RESULTS AND CONCLUSION:}

- It can be noted that as a whole our respondents identify themselves with the aims of their municipal hospital and assess highly its role and the services it provides. Atmosphere of trust and closeness is created among staff and patients which affects positively quality and efficiency of medical care.

- The municipal hospital is characterised by incredible orientation towards the needs of people, constant reporting on results and healthy feedback received from patients.

- All physicians, nurses, healthcare specialists and management regards patients' satisfaction from hospital treatment as integral and important tasks, which in return is highly appreciated by patients, demonstrated by their trust and choice for treatment in the municipal hospital. Patients' complaints are seriously inquired into and results are reported back to patients, which is again assessed positively by hospital customers.

- Quality of medical treatment, according to all respondents, is paramount for patients' satisfaction followed by politeness of medical staff and individual treatment. Comfort is ranked considerably lower.

- Patients consider information and communication between patients and physicians to be of highest significance.

- Patients assess highly qualification of medical staff, availability of equipment and service quality while remuneration of medical professionals is deemed unsatisfactory particularly with regards to the responsibility, knowledge and work load medical teams have.

Over the last years, patients' opinion of medical services receives a lot of attention and there is vast research on the topic. Results from our comprehensive study demonstrate three major trends: negative health and demographic status of Bulgarian population, inefficient health system and discrepancy between social and economic relations within the healthcare system and those in other spheres of public life. In fact, main reasons are linked to the human factor- both health employees and patients. The very low social status of medical specialists and inadequate remuneration for their work, in addition to the impossibility to provide modern day medicine for patients in poor regions and municipalities are the main and immediate causes of the state municipal health care is.

Indisputably there are also other factors which affect the health care system $[1,2,3,4,5$, $6,7,8,9,10,11,12,13]$ :

- Population aging as the single most significant demographic phenomenon of today's world, negative health and demographic indicators as well as increase of chronic diseases and invalidity;

- Constant shrinking of working age population both in real numbers and in relation to the total population due to low birth rate and intensive emigration of young people. The number of young people and employees who pay health contributions is also shrinking;

- The existing health system cannot provide adequate medical and dental treatment to Bulgarian population;

- Insufficient amount of financial resources and irrational use of existing resources for prophylaxis and prevention;

- The existing health system cannot respond adequately to the increased societal expectations for quality health services, state-of -the -art health technology and pharmaceuticals and demands for more comprehensive health information. 
The better living and economic standard of Bulgarian citizens and their active civic participation demand equal and unimpeded access to high standard health care that is timely and ensures quick and proper convalescence. The Bulgarian health systems needs to reform itself accordingly.

\section{REFERENCES:}

[1] Годишни отчети за дейността на НЗОК за 2012, 2013, 2014, 2015, 2016, 2017 година, София, България

[2] Димитров, Г. „Рискове и предизвикателства при реформиране на здравната система“, монография, изд. Св. Георги Богослов, България, 2018г.

[3] Доклад за здравето на нацията в началото на 21 век, анализ на провежданата реформа в здравеопазването, www.ncphp.government.bg, София, 2004 и 2007г.

[4] Доклад на Световната банка. Смекчаване на икономическото въздействие на застаряването на населението: Възможни варианти за България. София, 2013.

[5] Доклад за състоянието на здравето на нацията през 2012, Министерство на здравеопазването, 2015 г

[6] Евростат, Публикации. Анализи. База данни. www.epp.eurostat.ec.europa.eu

[7] Министерство на здравеопазването. Анализ на финансово-икономическото състояние и медико-статистическите показатели в лечебните заведения - тьрговски дружества. София, 2016.

[8] Национална стратегия за намаляване на бедността и насърчаване на социалното включване, България, 2020

[9] Национална стратегия за демографско развитие на населението в Република България(2012 - 2030 г.) МТСП, 2015.

[10] Национален социален доклад на Република България. 2013 - 2014 година. Министерски съвет, България

[11] Петрова, Зл., Стр. Генев, Управление на здравната система, Монография, Хелт медия. София, 2013г.

[12] Петрова, Зл. Т. Черкезов, Здравна политика, Управление на ресурсите и качеството на медицинските дейности сборник лекции, изд. МУ -София, 2017

[13] Петрова- Джеретто, Е., Проучване потребността от човешки ресурси в общинските болници, Дисертация за присъждане на образователна и научна степен 'доктор', 28.11.2018/ 19.03.2019

[14] Petrova- Geretto E., Zl. Petrova, „Migration processes in Bulgarian healthcare- motives and motivation",7th International Medical Congress, Batumi 7-10 September 2016

[15] Черкезов, Т. „Болничният мениджмънт в новите проекции на общественото здраве”, АБ, 2018 